ALRNATR

Paper ID \#6811

\title{
A Reflective Writing Assignment to Engage Students in Critical Thinking
}

Dr. Taryn Melkus Bayles, University of Maryland, Baltimore County 


\section{A Reflective Writing Assignment to Engage Students in Critical Thinking}

Our department has adopted the following Program Education Objectives, which we refer to as "the Five C's". Within three to five years after graduation our graduates will have demonstrated Competency in the discipline of chemical engineering; our graduates will have exhibited Critical thinking ability that has enabled them to solve complex problems; our graduates will have successfully achieved Cooperation goals through teamwork; our graduates will have demonstrated effective Communication and our graduates will have exhibited the Capacity for life-long learning. With these objectives in mind, our undergraduates have a wide variety of experiences, which support student outcomes, which define the set of learning outcomes representing knowledge, skills, and behaviors students should possess by the time of graduation in order to achieve the Program Educational Objectives. One of our specific student outcomes is to solve and analyze open-ended problems and another is to engage in critical thinking by evaluating design solutions. To this end, as part of a freshman engineering design course, our students were required to design, construct, test and evaluate a system, which would mimic the performance of a heart-lung machine. The goal of each design was to flow the five liters of 'blood' at an appropriate rate through their system, which was required to oxygenate and cool the 'blood'. Their design also had to minimize leaks and system volume. In addition to design, construction and testing, the teams were required to evaluate their system performance using theoretical calculations. This project provided an introduction to transport phenomena by combining momentum, heat and mass transfer. Two and a half years later, these same students matriculated into our chemical engineering program and completed their junior level courses in Transport Phenomena I (Fluids) and II (Heat and Mass Transfer). As part of their Transport Phenomena II class, the students were given their original freshman engineering design reports and were required to provide an analysis of their design. The analysis assignment was two-fold: the students were required to submit a group report re-analyzing the technical merits of their heart-lung design project and the students were required to submit an individual reflection paper. The group report analysis included: significance of design criteria, engineering design process and theoretical analysis of data collected. The idea behind the reflection assignment was to help the students clarify what they have studied and learned, integrate new knowledge with previous knowledge, as well as to help them become an active and aware learner so that they can better understand how they learn. Their reflection topics included: the engineering design process, engineering/math/science connections and technical writing.

This paper features a description of the design project challenge and solutions. Also included is the grading rubric, which was provided to the students to use as a guide for the reflection assignment. In addition, a summary of the group design analysis and the individual reflection assignments is provided. 


\section{Background}

For the last twelve years, the Introduction to Engineering Design course at the University of Maryland Baltimore County is a project-based learning engineering design course. The students work in teams to design, build, evaluate, test, report (both a formal written report and oral presentation) and develop a mathematical model for a specified product. It is a three-credit freshman-engineering course, which consists of two fifty-minute class sessions and a two-hour discussion session each week over a 16-week semester. The current enrollment in this course is approximately 240 students in the fall semester and 150 students in the spring semester.

Each year a different design project is assigned and the students must research, design, construct, and develop an analytical model and then test, evaluate, and report on the product. The goal is to select a product that is fun, inexpensive to construct, simple, and yet requires fundamental engineering principles. Safety is the primary concern, and the design specifications are structured to include safety precautions. The projects are also structured to have "bragging rights" associated with the product performance. This has resulted in friendly competition among the teams, but is not a grading criteria. Successful projects have included: human powered pumps, catapults or trebuchets for launching water balloons, hot air balloons, wooden block transport devices, hemodialysis systems, chemically powered vehicles, wireless sensors, renewable energy systems, contaminated water purification systems and heart-lung systems. The design project is introduced during class by having the students participate in hands-on activities.

\section{Freshman Course Goals}

The project based learning design projects have also allowed the course to fulfill additional goals of the Chemical, Biochemical and Environmental Engineering department's ABET objectives and outcomes, known as the "5 C's." According to the "5 C's," students should demonstrate, upon graduation, Competency in the discipline of chemical engineering, Critical thinking ability to solve complex problems, the ability to work in Cooperation with teammates, effective Communication skills, and Capacity for life-long learning. At the beginning of each semester a course objectives worksheet is provided to each student which indicates the ABET criteria which will be covered over the course of the semester. Although is it unlikely that a single freshman engineering course can prepare students to satisfy ABET criteria, it is a useful tool to gauge students' progress in their ability to utilize key engineering concepts and thought process. To this end, students are asked to provide a self-assessment, via a survey of their progress in key ABET areas, which were part of the course. Course survey results from three semesters are provided in Table 1 (the author was the course instructor for each of these semesters). This data is used to assess if there was a difference in the student's perception of the components of this course. The project based learning design projects allow students to critically design and analyze an open-ended problem, to cooperate with one another and, in the process, learn effective communication skills. However, by introducing a design project that places students into groups of 4-6 that are both diverse in terms of academic accomplishment and engineering field or other major of interest, the curriculum necessitates communication and cooperation. Because students in different fields of engineering are likely have different educational backgrounds and expertise, diverse groups necessitate communication in order to take full advantages of the cumulative knowledge of the group. 
Table 1: Freshman Introduction to Engineering Design: Student Assessment of ABET Criteria; Competency, Critical Thinking Cooperation with Teammates, Communication and Capacity for Life-Long Learning.

\begin{tabular}{|c|c|c|c|}
\hline \multicolumn{4}{|l|}{ Student Assessment of Course Outcomes } \\
\hline & Fall 2006 & Fall 2008 & Fall 2009 \\
\hline & $\mathrm{n}=182$ & $\mathrm{n}=194$ & $\mathrm{n}=186$ \\
\hline \multicolumn{4}{|l|}{ Competency } \\
\hline Ability to use math or science & 3.78 & 3.89 & 3.96 \\
\hline Proficiency in engineering & 3.09 & 2.94 & $4.03 *$ \\
\hline $\begin{array}{l}\text { Ability to design process using engineering } \\
\text { principles }\end{array}$ & 3.23 & 3.21 & $4.02 \dagger$ \\
\hline $\begin{array}{l}\text { Ability to use the techniques, skills and modern } \\
\text { engineering tools necessary for the practice of } \\
\text { engineering }\end{array}$ & 3.31 & 3.23 & $3.96 \$$ \\
\hline \multicolumn{4}{|l|}{ Critical Thinking } \\
\hline $\begin{array}{l}\text { Ability to analyze/solve open ended problems in } \\
\text { engineering }\end{array}$ & 3.19 & 3.10 & $3.89 \S$ \\
\hline $\begin{array}{l}\text { Ability to evaluate solutions or designs given } \\
\text { constraints }\end{array}$ & 3.87 & 3.94 & 4.09 \\
\hline \multicolumn{4}{|l|}{ Cooperation with Teammates } \\
\hline $\begin{array}{l}\text { Ability to work effectively in teams with others } \\
\text { having different backgrounds }\end{array}$ & 4.34 & 4.29 & 4.38 \\
\hline $\begin{array}{l}\text { Ability to fill both leadership and supporting roles in } \\
\text { a team }\end{array}$ & 4.22 & 4.30 & 4.31 \\
\hline \multicolumn{4}{|l|}{ Communication } \\
\hline Ability to communicate effectively in written form & 3.90 & 4.05 & 4.06 \\
\hline Ability to communicate effectively in an oral form & 3.96 & 4.07 & 4.03 \\
\hline \multicolumn{4}{|l|}{ Capacity for Life-Long Learning } \\
\hline $\begin{array}{l}\text { Ability to define problem given an open-ended } \\
\text { questions or situation }\end{array}$ & 3.95 & 3.89 & 4.11 \\
\hline $\begin{array}{l}\text { Ability to locate tools and information relevant to a } \\
\text { given problem }\end{array}$ & 3.96 & 3.92 & 4.13 \\
\hline $\begin{array}{l}\text { Ability to assimilate information relevant to a } \\
\text { problem }\end{array}$ & 3.95 & 3.95 & 4.09 \\
\hline $\begin{array}{l}\text { Ability to assess your own ability/knowledge to } \\
\text { solve a problem and determine when to seek help }\end{array}$ & 4.08 & 4.16 & 4.11 \\
\hline \multicolumn{4}{|l|}{$\begin{array}{l}\text { Statistically significant differences: }(p<0.05) \text { : } \\
* p=1.33 \mathrm{e}-14 ; \dagger p=4 \mathrm{e}-10 ;+p=4.44 \mathrm{e}-9 ; \S \mathrm{p}=2.86 \mathrm{e}-9\end{array}$} \\
\hline \multicolumn{4}{|c|}{$1=$ Not at all; $5=$ A great deal } \\
\hline
\end{tabular}

For each semester of the survey, the design projects were varied significantly to promote creativity and original ideas, they are all open-ended, have physical and economic constraints, require mathematical modeling, and require construction and testing of a finished product. The design project for the fall 2006 semester required the students to harness renewable energy (in the 
form of hydro, wind or solar energy), collect, store and transport the energy, and finally convert the energy to power a light-bulb; a full description of this design project was previously presented $^{(1,2)}$. In the fall 2008 semester, the design project $^{(3)}$ required students to design, construct, test and mathematically model the performance of a hot air balloon. An emphasis on communication required each team to complete their design, mathematical model and testing plans well in advance to their scheduled testing date. Each team gave their design project construction materials and design plans to another team, which constructed their design; and then the constructed projected was given to an evaluation team (while the original design team constructed and evaluated different designs). The design teams were returned their original designs and evaluations prior to final testing with the instructor. The design project for the fall 2009 semester required the students to design, test and mathematically model a system, which mimics a heart-lung system. Within a 15 minute testing period, the design had to process five liters of 'blood', maintain an 'appropriate' flow rate, oxygenate the blood a minimum amount of $3 \mathrm{mg} / \mathrm{l}$, cool the blood $5-8{ }^{\circ} \mathrm{C}$ and minimize the system volume (less than 1.5 liters). In addition, the designs had to minimize system leaks and cost. A complete description of the design project is provided in Appendix B. Provided below are some pictures taken during testing.
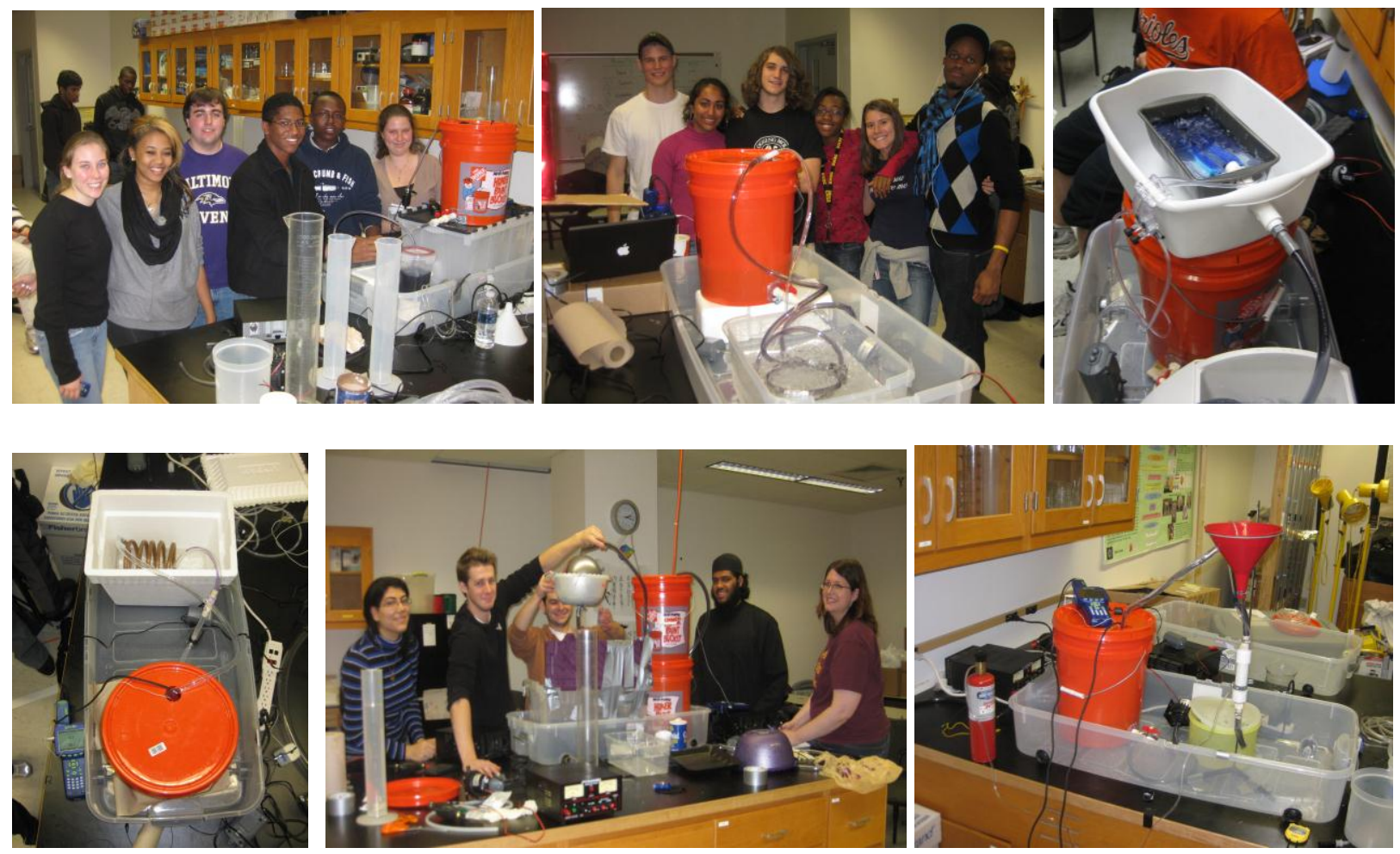

Figure 1: Various Heart-lung system design projects (Fall 2009).

\section{Critical Thinking / Reflection Writing Assignment}

In the fall 2009 semester, 200 freshman chemical engineering, computer engineering and mechanical engineering students were enrolled in the Introduction to Engineering Design course and completed the heart-lung system design project. Of these 200 students, 40 matriculated to 
the Chemical Engineering Transport II (Heat \& Mass Transfer) spring 2012 course (which the author also taught). As part of the course, the students were assigned a critical thinking/reflective writing assignment (worth $10 \%$ of their grade). The assignment was two-fold: the original design teams were required to submit a report re-analyzing the technical merits of their heartlung design project and then individually submit a reflection paper. The students were provided the original design project report which they submitted as freshmen two and a half years earlier (students who completed a different design project were paired with teams with only one or two original members - in addition, if they completed a different design project in a different semester, they were provided their original freshman design project report for their individual reflective writing assignment). Only $6 \%$ of the class did not receive their original design report, (they were transfer students and had completed the freshman engineering course at a community college or other four year university and these students used their community college freshman design reports for their reflective writing assignment - if they still had them or they based their reflective writing assignment on the design report which they re-analyzed for the technical merits of the project). For the group heart-lung design project analysis, the students were required to discuss the following topics:

- Significance of the design criteria (testing volume, system volume, flow rate, oxygenation, cooling, etc.)

- The engineering design process

- Analysis of the data collected (actual heat transfer/oxygenation versus theoretical analysis)

One of the student outcomes for the course is evidence of critical thinking - reflective writing can be evidence of critical thinking. The idea behind the reflective writing assignment was to help students understand that what they learn in their engineering curriculum builds on their prior knowledge. Reflective writing can help them develop and clarify the connection between what they already know and what they are learning (between theory and practice), as well as have a deeper understanding of how they learn. Reflection can help them clarify what they have done or studied, integrate new knowledge with previous knowledge, identify the questions they have and what they still need to learn. It can be helpful to reflect on mistakes, which can help avoid repeating them - while at the same time, reflecting on their discoveries help them to identify successful principles to use again. In addition, reflective writing helps them become active and aware learners, which helps them to become a reflective practitioner once they graduate and begin their professional career. The topics for their individual reflection paper included:

- The engineering design process

- Engineering/math/science connections

- Technical writing

The students were provided several resources ${ }^{(4-7)}$ to help them with this assignment. In addition, the students were provided a grading rubric (provided in Appendix A), prepared by the author which is a synthesis of other critical thinking rubrics ${ }^{(8-10)}$.

\section{$\underline{\text { Results }}$}

In the analysis of the original design solution, the most striking result was that less than half of the teams as freshman did not connect the design criteria to human constraints (blood volume, system volume, appropriate flow rate, oxygenation, cooling). Many of the teams did not maintain appropriate flow rates, which would correspond to a flow rate to maintain metabolic 
function during surgery. However, realization of the design criteria was instructive and provided a better appreciation of the design challenge. The majority of the teams indicated that as freshman they did not follow the engineering design process - rather they used a trial and error approach. However, they indicated that their teams were most successful in brainstorming different ideas for their design. The teams indicated that they did very few design calculations prior to design and construction, but performed the calculations for the report after the fact. Most teams discussed how their use of the design process has evolved over the last two and a half years and how the use of the process and mathematical models can benefit the final design. The theoretical analysis was most promising with statistical evidence of a greater than $50 \%$ increase in their mathematical model/theoretical analysis scores. A better understanding of Henry's law and determining convective heat transfer coefficients were apparent.

The individual reflections mirrored the group reports, however more details were provided and there was more evidence of critical thinking. In general, however, the students had difficulty integrating new knowledge with previous knowledge when discussing the engineering design process. Their lowest scores were in the 'depth of recognition of the complexity of the analysis' section - the students indicated that they still have another year of their degree program to help them with this analysis. Many students described in depth their perception that their first year of the curriculum was to introduce them to engineering and build fundamental math and science skills; their second year to introduce chemical engineering material and energy balances and learn how to design experiments and analyze data; their third year to delve in depth into transport, thermo and kinetics; and that they were looking forward to their senior year where they will learn to apply what they have learned in the first three years to be able to analyze complex systems. The students received their highest scores in the technical writing section and were able to provide the most tangible examples. It was most interesting to note, that in general, some of the strongest students in the class struggled the most with this assignment and received uncharacteristically low scores (this was not a result of end of the semester burn out - as they received very high scores on other end of the semester projects). These students had difficulty identifying the development of their understanding and felt that their knowledge has always been thorough.

The students writing assignments were also analyzed for common themes and the following words/themes were most often mentioned (the number of times appears in the parentheses):

Engineering Design Process:

- Trial and error (12)

- Not enough research (12)

- No calculations (11)

- Brainstorm (10)

- Not rooted in math and science (9)

- No prior testing (8)

- Better understanding of a 'system' (6)

- Design process not followed (6)

- Constraint/criteria (6)

Technical Writing:

- Formatting (17) 
- Not clear or not concise (16)

- Didn't explain tables and figures (14)

- Too long (12)

- No proofreading (10)

- Disorganized (8)

- No references (7)

Individual Reflection Summary:

- Better appreciation of math and science (14)

- How much they still need to learn (12)

- Critical thinking (10)

- How far they have come (9)

- Appreciation of team approach (8)

- Life-long learning (6)

As with the freshman introduction to engineering design course, the students in the Transport Phenomena II course are provided a course objectives worksheet which indicates the ABET criteria (the five C's - Competency in the discipline, Critical thinking ability, the ability to work in Cooperation with teammates, effective Communication skills and Capacity for life-long learning) which will be covered over the course of the semester. A single course in our curriculum will not satisfy the ABET criteria, however we have found that the end of the semester student surveys provide self-assessment as the students' progress through the curriculum. Course survey results for the last two years for the Transport Phenomena II course can be found in Table 2. The only difference in the course between the two years of the survey was the addition of the analysis of their freshman design project and reflective writing assignment. It is noteworthy that there was a statistically significant difference in the survey results for the following categories:

- Ability to design process using engineering principles

- Ability to evaluate solutions or designs given constraints

- Ability to analyze data to solve an engineering problem

- Ability to assess your own ability/knowledge to solve a problem and determine when to seek help

\section{Summary}

As reported by Colley et.al. ${ }^{(11)}$ reflective writing focusses learners' attention on their thinking by asking them to delve into their learning methods as well as their thoughts about specific topics. They have provided evidence that examining students reflective writing assignments, one can investigate the student's critical thinking. In this small study, the student self-assessment supports (with statistically significant differences) the idea that a reflective writing assignment provided students the opportunity to engage in critical thinking in the ability to evaluate solutions or designs and to analyze data. A statistically significant different was also reported in their ability to design a process using engineering principles - which is further validated with statistical evidence of a greater than 50\% increase in their mathematical model/theoretical analysis scores. In addition, this assignment also provided them the opportunity to assess their own ability/knowledge to solve a problem. 
Table 2: Transport Phenomena II: Student Assessment of ABET Criteria; Competency, Critical Thinking Cooperation with Teammates, Communication and Capacity for Life-Long Learning.

\begin{tabular}{|c|c|c|}
\hline \multicolumn{3}{|l|}{ Student Assessment of Course Outcomes } \\
\hline & Spring 2011 & Spring 2012 \\
\hline & $\mathrm{n}=48$ & $\mathrm{n}=42$ \\
\hline \multicolumn{3}{|l|}{ Competency } \\
\hline Ability to use math or science & 4.62 & 4.56 \\
\hline Proficiency in engineering & 4.71 & 4.77 \\
\hline $\begin{array}{l}\text { Ability to design process using engineering } \\
\text { principles }\end{array}$ & 4.08 & $4.59 *$ \\
\hline $\begin{array}{l}\text { Ability to use the techniques, skills and modern } \\
\text { engineering tools necessary for the practice of } \\
\text { engineering }\end{array}$ & 4.23 & 4.30 \\
\hline \multicolumn{3}{|l|}{ Critical Thinking } \\
\hline $\begin{array}{l}\text { Ability to analyze/solve open ended problems in } \\
\text { engineering }\end{array}$ & 4.61 & 4.56 \\
\hline $\begin{array}{l}\text { Ability to evaluate solutions or designs given } \\
\text { constraints }\end{array}$ & 3.94 & $4.41 \dagger$ \\
\hline $\begin{array}{l}\text { Ability to analyze data to solve an engineering } \\
\text { problem }\end{array}$ & 4.06 & $4.47 t$ \\
\hline \multicolumn{3}{|l|}{ Cooperation with Teammates } \\
\hline $\begin{array}{l}\text { Ability to work effectively in teams with others } \\
\text { having different backgrounds }\end{array}$ & 4.56 & 4.61 \\
\hline \multicolumn{3}{|l|}{ Communication } \\
\hline Ability to communicate effectively in written form & 4.39 & 4.20 \\
\hline Ability to communicate effectively in an oral form & 4.07 & 4.03 \\
\hline \multicolumn{3}{|l|}{ Capacity for Life-Long Learning } \\
\hline $\begin{array}{l}\text { Ability to define problem given an open-ended } \\
\text { questions or situation }\end{array}$ & 4.37 & 4.41 \\
\hline $\begin{array}{l}\text { Ability to assimilate information relevant to a } \\
\text { problem }\end{array}$ & 4.59 & 4.53 \\
\hline $\begin{array}{l}\text { Ability to assess your own ability/knowledge to } \\
\text { solve a problem and determine when to seek help }\end{array}$ & 4.23 & $4.73 \S$ \\
\hline \multicolumn{3}{|l|}{$\begin{array}{l}\text { Statistically significant differences: }(p<0.05) \text { : } \\
* p=2.49 \mathrm{e}-6 ; \dagger \mathrm{p}=7.86 \mathrm{e}-4 ;+\mathrm{p}=6.8 \mathrm{e}-4 ; \S \mathrm{p}=9.47 \mathrm{e}-6\end{array}$} \\
\hline & 1 = Not at all; & A great deal \\
\hline
\end{tabular}




\section{References}

1. Rice, J., T. M. Bayles, G. Russ, and J. Ross, "Preparing Freshmen for Future Energy Issues", Paper AC 20071748 published in the 2007 ASEE proceedings and presented in the Hands-on \& Real World Studies Session in The Freshman Programs Division Session.

2. Carletta, J., Bayles T.M., Kalveram, K., Khorbotly, S., Macnab, C., Nazhandali, L., Rice, J., Smith, J.A., Turner, L.E., Williams, S. and L. Wyard-Scott, "Special Session - Real World Engineering Projects: Discovery-Based Curriculum Modules for First-Year Students", Paper published in the Proceedings of the $39^{\text {th }}$ ASEE/IEEE Frontiers in Education Conference; presented in session T1A, San Antonio, TX, October, 2009.

3. Bayles, T.M., "Introduction to Engineering Design: An Emphasis on Communication", Paper AC-2009-1482 published in the 2009 ASEE proceedings and presentation in the Freshman Programs Division, San Antonio, TX, June 2009.

4. https://academicskills.anu.edu.au/resources/handouts/writing-reflective-marker-or-tute-paper, accessed April $10,2012$.

5. http://www.port.ac.uk/departments/studentsupport/ask/resources/handouts/writtenassignments/filetodownload,7 3259,en.pdf, accessed April 10, 2012.

6. Reidsema, C and P. Mort, "Assessing Reflective Writing: Analysis of Reflective Writing in an Engineering Design Course", Journal of Academic Language \& Learning, vol. 3, no. 2, 2009, pp. A-117-A129.

7. Ash, S.L., Clayton, P.H., and M.G. Moses, "Learning through Critical Reflection: A Student Tutorial", Center for Excellence in Curricular Engagement, North Carolina State University, 2008.

8. Alfrey, K., and E. Cooney, "Developing a Rubric to Assess Critical Thinking in Assignments with an Openended Component", Paper AC 2009-653 published in the 2009 ASEE proceedings.

9. Bailey, R., and Z. Szabo, "Assessing Engineering Design Process Knowledge", Journal of Engineering Education, vol. 22, no. 3, pp. 508-518.

10. Moses, M., "Critical Reflection in Service-Learning: Generating, Deepening, and Documenting Learning Challenges, Strategies and Activities", Duke University, Service-Learning Program.

11. Colley, Binta M. PhD; Bilics, Andrea R. PhD; and Lerch, Carol M. PhD (2012) "Reflection: A Key Component to Thinking Critically," The Canadian Journal for the Scholarship of Teaching and Learning: Vol. 3: Issue 1, Article 2, pp. 1-19. 


\section{Appendix A: Transport Phenomena II - Reflective Writing / Critical Thinking Rubric}

\begin{tabular}{|c|c|c|c|c|c|c|c|}
\hline & Novice (1) & Developing (2) & Proficient (3) & Exemplary (4) & \multicolumn{3}{|c|}{ Score } \\
\hline & & & & & DP & MS & TW \\
\hline $\begin{array}{l}\text { Defining the } \\
\text { problem }\end{array}$ & $\begin{array}{l}\text { Takes problem as } \\
\text { stated without regard } \\
\text { to relevance (repeat } \\
\text { what is 'true but not } \\
\text { useful') }\end{array}$ & $\begin{array}{l}\text { Determine what is } \\
\text { relevant \& what is } \\
\text { not }\end{array}$ & $\begin{array}{l}\text { Gives voice to what } \\
\text { other information is } \\
\text { needed to solve } \\
\text { problem }\end{array}$ & $\begin{array}{l}\text { Identifies and clearly } \\
\text { state both the main } \\
\text { question sand } \\
\text { subsidiary, embedded } \\
\text { or implicit aspects of } \\
\text { the question }\end{array}$ & & & \\
\hline $\begin{array}{l}\text { Integration / } \\
\text { Connection } \\
\text { between } \\
\text { Experience \& } \\
\text { Learning } \\
\end{array}$ & $\begin{array}{l}\text { Provides no clear } \\
\text { connection between } \\
\text { the experience and the } \\
\text { learning }\end{array}$ & $\begin{array}{l}\text { Provides minimal } \\
\text { and/or unclear } \\
\text { connection between } \\
\text { the experience and } \\
\text { the learning }\end{array}$ & $\begin{array}{l}\text { Provided adequate and } \\
\text { reasonably clear } \\
\text { connection between } \\
\text { the experience and the } \\
\text { learning }\end{array}$ & $\begin{array}{l}\text { Provides thorough } \\
\text { and very clear } \\
\text { connections between } \\
\text { the experience and } \\
\text { the learning }\end{array}$ & & & \\
\hline $\begin{array}{l}\text { Relevance of } \\
\text { Learning to } \\
\text { the Learning } \\
\text { Goal }\end{array}$ & $\begin{array}{l}\text { Misclassifies the } \\
\text { learning and/or } \\
\text { inappropriately shifts } \\
\text { from one category of } \\
\text { learning goal to } \\
\text { another: fails to keep } \\
\text { the discussion specific } \\
\text { to the learning }\end{array}$ & $\begin{array}{l}\text { Discusses learning } \\
\text { that is relevant to the } \\
\text { category of learning } \\
\text { goal, but much of the } \\
\text { discussion is not } \\
\text { related to the learning }\end{array}$ & $\begin{array}{l}\text { Discusses learning that } \\
\text { is relevant to the } \\
\text { category of learning } \\
\text { goal and keeps the } \\
\text { discussion reasonably } \\
\text { well focused on the } \\
\text { learning }\end{array}$ & $\begin{array}{l}\text { Discusses learning } \\
\text { that is relevant to the } \\
\text { category of learning } \\
\text { goal and keeps that } \\
\text { discussion well- } \\
\text { focused on the } \\
\text { learning }\end{array}$ & & & \\
\hline $\begin{array}{l}\text { Accuracy of } \\
\text { Applying } \\
\text { Academic } \\
\text { Concepts }\end{array}$ & $\begin{array}{l}\text { Consistently makes } \\
\text { inaccurate statement } \\
\text { and/or fails to provide } \\
\text { supporting evidence } \\
\text { for claims } \\
\text { Academic category - } \\
\text { incorrectly identifies, } \\
\text { describes, and/or } \\
\text { applies academic } \\
\text { concepts }\end{array}$ & $\begin{array}{l}\text { Makes several } \\
\text { inaccurate statements } \\
\text { and/or supports few } \\
\text { statements with } \\
\text { evidence } \\
\text { Academic category - } \\
\text { not accurate in } \\
\text { identifying, } \\
\text { describing and/or } \\
\text { applying academic } \\
\text { concepts }\end{array}$ & $\begin{array}{l}\text { Usually but not always } \\
\text { makes statements that } \\
\text { are accurate and well- } \\
\text { supported with } \\
\text { evidence } \\
\text { Academic category - } \\
\text { accurately identifies, } \\
\text { describes, and applies } \\
\text { appropriate academic } \\
\text { concepts }\end{array}$ & $\begin{array}{l}\text { Consistently makes } \\
\text { statement that are } \\
\text { accurate and well- } \\
\text { supported with } \\
\text { evidence } \\
\text { Academic category - } \\
\text { accurately identifies, } \\
\text { describes, and } \\
\text { applies appropriate } \\
\text { academic concepts }\end{array}$ & & & \\
\hline $\begin{array}{l}\text { Precision / } \\
\text { Clarity } \\
\text { Provides } \\
\text { Specific } \\
\text { Information / } \\
\text { Data }\end{array}$ & $\begin{array}{l}\text { Consistently fails to } \\
\text { provide specific } \\
\text { information, } \\
\text { descriptions or data }\end{array}$ & $\begin{array}{l}\text { Only occasionally } \\
\text { provides specific } \\
\text { information, } \\
\text { descriptions or data }\end{array}$ & $\begin{array}{l}\text { Usually but not always } \\
\text { provides specific } \\
\text { information, } \\
\text { descriptions or data }\end{array}$ & $\begin{array}{l}\text { Consistently provides } \\
\text { specific information, } \\
\text { descriptions or data }\end{array}$ & & & \\
\hline $\begin{array}{l}\text { Depth } \\
\text { Recognition of } \\
\text { the } \\
\text { Complexity of } \\
\text { the Problem } \\
\text { and/or } \\
\text { Assignment }\end{array}$ & $\begin{array}{l}\text { Fails to address salient } \\
\text { questions that arise } \\
\text { from statements being } \\
\text { made; consistently } \\
\text { over-simplifies when } \\
\text { making connections; } \\
\text { fails to consider any of } \\
\text { the complexities of the } \\
\text { issue }\end{array}$ & $\begin{array}{l}\text { Addresses few of the } \\
\text { salient questions that } \\
\text { arise from statement } \\
\text { being made; often } \\
\text { over-simplifies when } \\
\text { making connections; } \\
\text { considers little of the } \\
\text { complexity of the } \\
\text { issue }\end{array}$ & $\begin{array}{l}\text { Addresses some but } \\
\text { not all of the salient } \\
\text { questions that arise } \\
\text { from statements being } \\
\text { made; rarely over- } \\
\text { simplifies when } \\
\text { making connections; } \\
\text { considers, some but } \\
\text { not all of the full } \\
\text { complexity of the issue }\end{array}$ & $\begin{array}{l}\text { Thoroughly } \\
\text { addresses salient } \\
\text { questions that arise } \\
\text { from statements } \\
\text { being made: avoids } \\
\text { over-simplifying } \\
\text { when making } \\
\text { connections: } \\
\text { considers the full } \\
\text { complexity of the } \\
\text { issue }\end{array}$ & & & \\
\hline $\begin{array}{l}\text { Significance of } \\
\text { the Experience } \\
\text { provided in } \\
\text { the } \\
\text { Conclusions }\end{array}$ & $\begin{array}{l}\text { Draws conclusions } \\
\text { that don't address the } \\
\text { most significant issue } \\
\text { raised by the } \\
\text { experience }\end{array}$ & $\begin{array}{l}\text { Draws conclusions } \\
\text { that only minimally } \\
\text { address the } \\
\text { significant issue } \\
\text { raised by the } \\
\text { experience }\end{array}$ & $\begin{array}{l}\text { Draws conclusions } \\
\text { that usually address } \\
\text { fairly significant issues } \\
\text { raised by the } \\
\text { experience }\end{array}$ & $\begin{array}{l}\text { Draws important } \\
\text { conclusions that } \\
\text { substantially address } \\
\text { the most significant } \\
\text { issue raised by the } \\
\text { experience }\end{array}$ & & & \\
\hline Writing & $\begin{array}{l}\text { Consistently makes } \\
\text { typographical, spelling } \\
\text { and/or grammatical } \\
\text { errors }\end{array}$ & $\begin{array}{l}\text { Makes several } \\
\text { typographical, } \\
\text { spelling, and/or } \\
\text { grammatical errors }\end{array}$ & $\begin{array}{l}\text { Makes few } \\
\text { typographical, } \\
\text { spelling, and/or } \\
\text { grammatical errors }\end{array}$ & $\begin{array}{l}\text { Makes very few or no } \\
\text { typographical } \\
\text { spelling and/or } \\
\text { grammatical errors }\end{array}$ & & & \\
\hline
\end{tabular}




\section{Appendix B: Heart-Lung System Design Challenge}

Your team is to design, construct, test, and evaluate a system that will simulate the performance of a heart-lung machine. Your goal is to flow the 'blood' through your system, which is required to oxygenate and cool the 'blood' while minimizing leaks and the amount of 'blood' within your system. You will be allotted 5 minutes to setup the system at the test site and it must fit within the specified area. You will have a maximum of 15 minutes to process the 'blood'. All team members must be present during the system testing / evaluation. You are encouraged to check your design well in advance of your testing / evaluation date. When you have completed the evaluation, dispose of your device in an environmentally sensitive manner. If the system is operational at the end of the test, perhaps your team will be interested in donating it to the Chemical and Biochemical Engineering Department for demonstrations to future classes.

Your primary criterion for this design project is SAFETY. Your system must operate without any hazards.

Keeping SAFETY in mind, the following restrictions are placed on the design:

Your team must provide and justify all of the components of your system. The system will be tested using a volume of 5 liters of 'blood'. The maximum amount of 'blood' in your heart-lung system (including any 'blood' lost via leaks from the system) is 1.5 liters. The system should maximize the oxygenation of the 'blood' - the minimum increase of dissolved oxygen content must be at least $3 \mathrm{mg} / \mathrm{l}$. The system must also cool the 'blood' - the minimum change in temperature is $\Delta \mathrm{T}$ minimum $=5{ }^{\circ} \mathrm{C}$ and the maximum change is $\Delta \mathrm{T}$ maximum $=8{ }^{\circ} \mathrm{C}$. Your team must select and justify the appropriate flow rate for the system. Your team will have a variety of pumps to use during testing (the cost of these pumps will not be included in your system cost). The cost of your system must be less than $\$ 50.00$ (all materials used in your design are considered to be purchased new, as if you were prototyping the device for production - i.e., even if you use 'found' materials, you must cost them as if they were new). Non-functional decorations do not need to be included in the cost (i.e., paint, marker, stamps, decals, etc.).

Product performance: "Bragging rights" for the heart-lung system performance will be assessed using the performance metric:

Flow rate (l/min) $x \quad \Delta$ in Dissolved Oxygen $(\mathrm{mg} / \mathrm{l}) \times \Delta$ in Temperature ${ }^{\circ}(\underline{C}) x$ System Cost Index Your Heart-Lung System Simulated Blood Volume [including leaks] (liters)

The device cost index is calculated using:

Minimum TOTAL design cost of a heart-lung system that meets the design requirements Your Team TOTAL design cost

You are expected to report on your progress using different design reviews. A Design Review is an activity that allows your supervisors, customers, sponsors, clients, etc., to assess 
your progress in achieving the desired project goals and outcomes. Design reviews are often milestones that must be satisfactorily passed before you are permitted to continue with the project. You will be expected to provide the following for your reviews:

A design notebook with all the team's work to date: Part of the decision about whether to approve further work is based on the belief that the team is following a sound process and making good decisions as it progresses. Reviewers will also want to feel that the team is putting in the expected level of effort. The design notebook is the primary source of evidence to justify these concerns. Most design notebooks will contain at least the following items:

- Purpose, goals, motivation of project

- Brief project history (normally identifying all important decisions made and how they were made and demonstrating team skills)

- Description of Design, Implementation, and Evaluation Approaches (including problem definition and solution generation approaches)

- Preliminary Designs including how and why they were modified into the final design

- A clear presentation of Final Design (using words and graphics, with explanations of design feature, constraints, and 'goodness' criteria, and showing progress from preliminary to final designs)

- A formal report:

This report will allow you to summarize your efforts. Here you will give an overview of what has been accomplished and discuss the overall learning that has taken place as you worked on the project. As this is a formal report, it should consist of descriptive text written in complete sentences and paragraphs. Include figures, tables, graphs, and completed templates to support the text. Any figures, tables, plots, etc., should be integrated with the text to make a "seamless whole".

An oral presentation: Each team will give an oral presentation of their work, and each team member must give part of the oral presentation. The presentation will focus on the design process and on the overall system efficiency. As the presentations will occur after the testing date, your team will be asked to address how their design (based on theoretical understanding of a heart-lung machine) compared to their system's performance during the testing.

\section{Deadlines:}

Testing of your system will take place during the week of November 30, 2009, during your discussion session. The final design package (notebook and report) is due at NOON on Friday, December 4, 2009 for ENES 101H section 4462 and ENES 101Y sections 4464 and 4467 and ENES 101 section 4460; the final design package (notebook and report) is due at NOON on Monday, December 7, 2009 for ENES 101 sections 4457, 4458 and 4459. The oral presentations will take place the week of December 7, 2009 during the discussion sessions. Handouts will be distributed in lecture with the formal report and oral presentation guidelines and grading rubrics. 